\title{
A Study of Carbon Dioxide Emission in Different Types of Peatland Use in Kalimantan
}

\author{
Nyahu Rumbang ${ }^{1}$ \\ ${ }^{1}$ Student of Soil Science, Faculty of Agriculture, Gadjah Mada University
}

\begin{abstract}
Study of carbon dioxide emissions in different types of peatlands use in Central and West Kalimantan has been conducted in January-June 2006 and January-April 2007. The study represents 4 types of land use in Central Kalimantan as treatment: 5 years for chinesse cabbage, 10 years for chinesse cabbage, 5 years for sweet corns, and 10 years for sweet corns. As for the treatments in West Kalimantan, they include corn field, Aloe vera field, oil palm plantation, and rubber plantation. Carbon dioxide was measured using infrared gas analysis (model EGM-4, PP systems, Hitchin, UK). In Central Kalimantan, the highest $\mathrm{CO}_{2}$ is emitted from sweet corn plants (arable land for 10 years) by $0.79 \mathrm{~g} \mathrm{CO}_{2} / \mathrm{m}^{2} /$ hour, chinesse cabbage plants (for 5 years) by $0.73 \mathrm{~g} \mathrm{CO}_{2} / \mathrm{m}^{2} /$ hour, chinesse cabbage plants (for 10 years) by $0.67 \mathrm{~g} \mathrm{CO}_{2} / \mathrm{m}^{2} /$ hour and, the least, sweet corn plants (for 5 years) by $0.41 \mathrm{~g} \mathrm{CO}_{2} / \mathrm{m}^{2} /$ hour. The highest $\mathrm{CO}_{2}$ emission from West Kalimantan is released from rubber plants at $1.22 \mathrm{~g} \mathrm{CO}_{2} / \mathrm{m}^{2} /$ hour, followed by palm oil plants by $0.96 \mathrm{~g}$ $\mathrm{CO}_{2} / \mathrm{m}^{2} /$ hour, Aloe vera plants by $0.68 \mathrm{~g} \mathrm{CO}_{2} / \mathrm{m}^{2} /$ hour and corn plants by $0.35 \mathrm{~g} \mathrm{CO}_{2} / \mathrm{m}^{2} /$ hour. Groundwater table depth are the most important factors among other factors that influence $\mathrm{CO}_{2}$ emissions. Groundwater table depth indicated a positive correlation with $\mathrm{CO}_{2}$ emissions in all types of peatlands use. C-organic production of sweet corn plants at $11.66 \mathrm{t} \mathrm{C} / \mathrm{ha} /$ year is higher than that of chinesse cabbage plants at $1.64 \mathrm{t}$ $\mathrm{C} / \mathrm{ha}$ /year. Corn plants produce organic- $\mathrm{C}$ was $11.66 \mathrm{t} \mathrm{C/ha/year,} \mathrm{equivalent} \mathrm{to} \mathrm{the} \mathrm{amount} \mathrm{of} \mathrm{loss} \mathrm{of} \mathrm{C}$ through $\mathrm{CO}_{2}$ emissions by $11.29 \mathrm{t} \mathrm{C/ha/year}$.
\end{abstract}

Keywords: peat, types of land use, carbon, $\mathrm{CO}_{2}$ emission

\section{INTRODUCTION}

Ecological functions of tropical peatlands are to store carbon, to balance the carbon composition, to pin nutrient-trapping sediments, and to stabilize the microclimate (Page et al., 2004; Rieley, 1992 and Rieley et al., 2008). Peat land conversion to agriculture will disrupt the ecological functions of peatlands. This happens due to the reclamation of peatlands to agricultural land that includes the creation of drainage to remove excess water in order to decrease water table depth. Syarkowi (2007) noted that the sweet corn and chinesse cabbage plants are two most profitable commodities for farmers in Kalampangan.

The decrease in the depth of groundwater table resulted in changes in the conditions of peat on the top layer, from anaerobic to aerobic condition. In this aerobic condition oxidation of carbon occurs to generate carbon dioxide released into the atmosphere. $\mathrm{CO}_{2}$ emission released into the atmosphere impacts not only global warming, due to its very large contribution, but also threatens the existence of peatlands as the carbon storehouses.
Utilization of peatlands for agriculture purposes affects the environmental changes. Environmental factors such as the depth of groundwater table, temperature, humidity and peatland $\mathrm{pH}$ affect the magnitude of emitted $\mathrm{CO}_{2}$ released by peatlands (Jauhiainen et al., 2005; Hooijer et al., 2006; Agus et al., 2010; Jauhiainen and Hooijer., 2012).

Plant biomass productions in peatlands are still relatively low, and therefore no balance was found between the ability of plants to produce carbon and the carbon loss through $\mathrm{CO}_{2}$ emissions. This condition is made worse by the fact that nearly all the biomass produced, especially by annual crops, were transported out so that almost no biomass restored in the soil. The impact will not only on peat loss due to subsidence, but also the emitted $\mathrm{CO}_{2}$ itself as one source of greenhouse gas.

The research aims (1) to determine the amount of $\mathrm{CO}_{2}$ emitted by various types of peatlands use, (2) to determine the correlation between environmental factors as well as other factors and the amount of $\mathrm{CO}_{2}$ emitted by different types of peatlands use, and (3) to determine the ability of various types of peatlands 
use in producing carbon to substitute the carbon lost through $\mathrm{CO}_{2}$ emissions. The results of this study are expected to useful to understand the magnitude of peat loss through $\mathrm{CO}_{2}$ emissions from various types of land use, and to maintain a balance between the release of carbon through $\mathrm{CO}_{2}$ emissions and carbon sequestration by plants.

Peatlands constitute an accumulation of soil organic matter in the form of stems, twigs, leaves, and roots as the raw material in waterlogged conditions (Andriesse, 1988). Accumulation of organic matter occurs when the produced of organic matter is higher than the decomposed organic matter. This occurs in a condition that is not optimal for the decomposition process (Collins and Kuehl, 2001).

Ecologically, peatlands serve, among others, as a storehouse of carbon. In case of ecological function disturbance, peatlands have a huge potential to release $\mathrm{CO}_{2}$ into the atmosphere. Peat swamp forests conversion into agricultural land is one source of $\mathrm{CO}_{2}$ emissions (Hooijer et al., 2006). According Kawahigashi and Sumida (2006), fertilizer applied in high dose will accelerate decomposition.

Emitted gases contributing to the greenhouse effect include carbon dioxide (48\%), freon $(26 \%)$, ozone $(10 \%)$, methane $(8 \%)$ nitrous oxide (6\%), and other gases (2\%) (Pirkko, 1990). Meanwhile, according to the IPCC report (2001), carbon dioxide, methane and nitrous oxide contributed very significantly to the global warming by $60 \%, 20 \%$ and $6 \%$, respectively.

The results of a study by Jauhiainen et al. (2008) demonstrated that $\mathrm{CO}_{2}$ emissions from drained peatland forests or secondary forests amount to approximately $0.84 \mathrm{~g} \mathrm{CO}_{2} / \mathrm{m}^{2} /$ hour. The results differ only slightly from those of Melling (2005) indicating that secondary forest in Sarawak emitted $0.89 \mathrm{~g} \mathrm{CO}_{2} / \mathrm{m}^{2} /$ hour. Carbon dioxide emitted by undrained peat swamp ranges from 0.40 to $0.50 \mathrm{~g} \mathrm{CO}_{2} / \mathrm{m}^{2} /$ hour (Inubushi et al., 2003; Jauhiainen et al., 2005).

Recovered forest after deforestation emits 0.30 - $0.32 \mathrm{~g} \mathrm{CO}_{2} / \mathrm{m}^{2} /$ hour, higher than the $\mathrm{CO}_{2}$ emitted by abandoned agricultural land that amount to $0.22 \mathrm{~g} \mathrm{CO}_{2} / \mathrm{m}^{2} /$ hour (Jauhiainen et al., 2004), yet even lower than the emissions by oil palm land and sago land at $0.65 \mathrm{~g} \mathrm{CO}_{2} / \mathrm{m}^{2} /$ hour and $0.46 \mathrm{~g} \mathrm{CO}_{2} / \mathrm{m}^{2} /$ hour, respectively (Melling, 2005). Hatano et al. (2004) showed that the $\mathrm{CO}_{2}$ emitted by Kalampangan vegetable farms ranged from 0.23 to $1.02 \mathrm{~g} \mathrm{CO}_{2} / \mathrm{m}^{2} /$ hour. Highest $\mathrm{CO}_{2}$ emission was released by Acacia plantations in Riau at $1.07 \mathrm{~g} \mathrm{CO}_{2} / \mathrm{m}^{2} /$ hour with groundwater table depth of $0.80 \mathrm{~m}$ (Jauhiainen and Hooijer, 2012).

Carbon dioxide emission from the soil is the result of respiration process, which means a process of decomposition of organic molecules into energy, water and $\mathrm{CO}_{2}$ in cells. The emitted carbon dioxide can be derived from the results of the root respiration, microbial respiration in the rhizosphere, respiration and decomposition of litters and organisms, or respiration of soil organic matter oxidation (Luo and Zhou, 2006; Moyano et al., 2010).

Environmental factors such as the depth of groundwater table, temperature, humidity and $\mathrm{pH}$ greatly influence the magnitude $\mathrm{CO}_{2}$ emitted by peatlands (Jauhiainen et al., 2001; Hooijer et al., 2006; Strack, 2008; Agus et al., 2010). Different types of peatland use have resulted environmental changes such as groundwater table depth, soil and air temperatures. Differences in agricultural cultivation and treatment due to different types of land use have resulted in differences in the physical, chemical and biological properties of the soil. Environmental differences and differences in physical, chemical and biological properties of peatland are assumed to correlate with the amount of $\mathrm{CO}_{2}$ emitted by peatlands.

Carbon emissions and sequestration in peatlands take place simultaneously, but the magnitude of both boils down to the ecological condition and human intervention. Thus, one strategy that can be done to reduce the amount of $\mathrm{CO}_{2}$ emitted by the peatlands is by setting the proper water table depth, according to the depth of groundwater level optimal for plants. On the other hand, to offset the amount of $\mathrm{CO}_{2}$ released by peatlands, selection of plant species potential to generate carbon is an equally important strategy.

Improper management of peatlands resulted in carbon loss from the peatlands due to increased release of carbon dioxide into the atmosphere. Thus, the study of carbon dioxide emissions from various types of peatland use is very important. 
Ecological functions of tropical peatlands are to store carbon, to balance the carbon composition, to pin nutrient-trapping sediments, and to stabilize the microclimate. Peatland conversion to agriculture will disrupt the ecological functions of peatlands, which increased the release of $\mathrm{CO}_{2}$ from the soil. The release of $\mathrm{CO}_{2}$ is influenced by biotic and abiotic factors. In tropical peatlands, release of $\mathrm{CO}_{2}$ is influenced by the depth of the groundwater table (Hirano et al., 2007).

Decreased depth resulted in changes in the condition of the peat upper layer, from anaerobic conditions to aerobic conditions. In aerobic conditions, oxidation of carbon occurred to yield carbon dioxide released into the atmosphere (Lou and Zhou, 2006). Conversion of peat swamp forest is a source of $\mathrm{CO}_{2}$ emissions (Hooijer et al., 2006). Fertilizing with a high dose will accelerate decomposition (Kawahigashi and Sumida, 2006).

The carbon dioxide can be derived from the process of root respiration, rhizosphere respiration, respiration from litter decomposition or soil organic matter oxidation (Luo and Zhou., 2006; Moyano et al., 2010). Factors that affect the amount of respiration are substrate availability, temperature, soil moisture, availability of oxygen, nitrogen, soil $\mathrm{pH}$ and the interaction between these factors (Luo and Zhou, 2006; Reddy and Delaune, 2008).

Different types of peatlands use lead to environmental changes such as groundwater table depth, soil and air temperatures. Differences in agricultural cultivation and in treatment due to different types of land use resulted in differences in the physical, chemical and biological properties of peat. Differences in ecology and in the physical, chemical and biological properties of peat are assumed to correlate with differences in the amount of $\mathrm{CO}_{2}$ emitted.

Carbon emissions and sequestration in peatland take place simultaneously, but the amount of each depends on the ecological condition and human intervention. In the natural forest conditions that are generally water saturated, carbon sequestration last shorter than the decomposition, resulting in the growth of peat. In contrast, on the land managed for agricultural purposes, carbon decomposition occurs faster than carbon sequestration, resulting in peat subsidence.

To preserve the peat means to keep the balance between $\mathrm{CO}_{2}$ emissions from peatlands and carbon sequestration by plants. One strategy to maintain the balance is by controlling the depth of the groundwater table because it is a factor that most significantly affects the amount of $\mathrm{CO}_{2}$ emissions. On the other hand, the plants cultivated on peatlands should have a high potential for carbon emission, and it is necessary to make sure that the sequestrated carbons are not entirely transported out of the soil. In reality, the biomass in most horticultural crops cultivated on peatlands transported out and thus it left only in a small fraction in the soil.

\section{MATERIALS AND METHODS}

The study was conducted in two provinces: Central Kalimantan and West Kalimantan, within two years of the study period from January to June 2006 and January to April 2007. In Central Kalimantan, the research was conducted in the Village of Kalampangan, Sabangau District, Palangka Raya City. In Kalampangan research, 4 types of peatlands use that serve as treatments constitute a combination of duration of managed land and crop species. The four types of land use are: (1) 5 years for chinesse cabbage, (2) 10 years for chinesse cabbage, (3) 5 years for sweet corns, and (4) 10 years for sweet corns. Each type of land use is represented by three farmers' fields.

The research in West Kalimantan covers 4 types of land use, each at a different location. The four types of land use are: (1) corn field in Rasau Jaya, (2) Aloe vera field in Siantan Hulu, (3) oil palm plantation in Sungai Ambawang and (4) rubber plantation in Sungai Ambawang. The corn field, Aloe vera field and rubber plantation each represented by 3 farmers' land, while the oil palm plantation is represented by 3 blocks of field.

Aspects observed include $\mathrm{CO}_{2}$ emissions, soil, and biomass production. The method used to measure $\mathrm{CO}_{2}$ emission from peatlands by using infrared gas analysis (model EGM-4, PP systems, Hitchin, UK). Along with the measurement of $\mathrm{CO}_{2}$ emissions, the depth of groundwater table, air temperature and soil temperature at depths of 10 , 20,30 and $40 \mathrm{~cm}$ were also measured.

The soil measurement aspects include analysis of bulk density, organic matter content, C-organic content, total bacteria, $\mathrm{pH}\left(\mathrm{H}_{2} \mathrm{O}\right)$, the content of N, P, K, Ca, Mg, Cu and Zn-total. Peat sampling was conducted using a special drill, Edjelkamp. Peat examples of all types of land use in each replication were taken from three depths: $0-15 \mathrm{~cm}, 15-45 \mathrm{~cm}$ and $45-100 \mathrm{~cm}$. 
Plant biomass production only occurs on chinesse cabbage field and sweet corn field in Central Kalimantan. Chinesse cabbage plants biomass include the roots, stems and leaves, while the corn plants biomass include roots, stems, leaves and corn skins.

\section{RESULTS AND DISCUSSION}

\section{Characteristics of Peat}

Bulk density of peat in 4 types of land use in Central Kalimantan ranged from 0.13 to 0.15 $\mathrm{g} / \mathrm{cm}^{3}$, similar to that in 4 types of peatland use in West Kalimantan that ranged from 0.13 to 0.16 $\mathrm{g} / \mathrm{cm}^{3}$. Based on the degree of decomposition, both peat derived from Central Kalimantan and West Kalimantan belongs in suborde Hemist.

Different types of land use resulted in differences in the $\mathrm{pH}$ of peat and this happens at all levels of peat depth. Such differences also lead to differences in the $\mathrm{pH}$ of peat and in all types of land use. This difference occurs in both the peat from Central Kalimantan and from West Kalimantan.

On the research in Central Kalimantan, the peat samples were from the depths of $0-15 \mathrm{~cm}$, $15-45 \mathrm{~cm}$ and $45-100 \mathrm{~cm}$ with $\mathrm{pH}\left(\mathrm{H}_{2} \mathrm{O}\right)$ values ranged from 3.30 to $3.50,3.23$ to 3.37 and 3.00 to 3.20, respectively. As for the research in West Kalimantan, peat samples were taken from the depths of 0-15 cm, $15-45 \mathrm{~cm}$ and $45-100 \mathrm{~cm}$ with $\mathrm{pH}\left(\mathrm{H}_{2} \mathrm{O}\right)$ values ranged from 3.23 to $3.83,3.20$ to 3.87 and 2.87 to 3.57 , respectively. Both in Central Kalimantan and West Kalimantan, $\mathrm{pH}$ $\left(\mathrm{H}_{2} \mathrm{O}\right)$ values decreased with the peat depth.

In the four types of peatlands use in Central Kalimantan macro nutrients like N, P, K, $\mathrm{Ca}$ and $\mathrm{Mg}$-total were found in different amount, except for N-total at a depth of $45-100 \mathrm{~cm}$ and Ptotal at a depth of $0-15 \mathrm{~cm}$. This was also the case for peatlands in West Kalimantan, where in four types of peatlands use nutrients $\mathrm{N}, \mathrm{P}, \mathrm{K}, \mathrm{Ca}$ and Mg-total were found in different amount, except for $\mathrm{N}$-total at a depth of $45-100 \mathrm{~cm}$. In general, the content of $\mathrm{N}, \mathrm{P}, \mathrm{K}, \mathrm{Ca}$ and $\mathrm{Mg}$-total decreased with depth of the peat.

The peat originating from Central Kalimantan contains nutrients of Cutotal on the four types of land use that were not significantly different, except at a depth of 15-45 cm. Similarly, the nutrient content of Zn-total shows no significant differences in the four types of peatland use, except at a depth of $0-15 \mathrm{~cm}$. The peat derived from West Kalimantan contains nutrients of $\mathrm{Cu}$ and $\mathrm{Zn}$-total that were significantly different among the types of peatland use, especially at a depth of $0-15 \mathrm{~cm}$ and $15-45$ $\mathrm{cm}$, but not significantly different at a depth of 45$100 \mathrm{~cm}$.

On all types of peatland use in Central Kalimantan, the peat depth factor causes differences in the content of Cu-total. The Content of $\mathrm{Zn}$-total indicates also the difference between the levels of peat depth on all types of land use, except for the chinesse cabbage (for 5 years). In West Kalimantan, peat depth factor affects the total content of $\mathrm{Cu}$-total of Aloe vera field and oil palm plantation. In addition, peat depth was also affect the the $\mathrm{Zn}$-total content on Aloe vera field, rubber plantation and corn fields.

Both research in Central Kalimantan and West Kalimantan, on all levels of peat depth, indicate that the C-organic content was not significantly different among the types of land use. Based on the factors of peat depth in research conducted in Central Kalimantan, C-organic content was significantly different between the depths of peat and this occurs in all types of land use. The content of C-organic at a depth of 0-15 $\mathrm{cm}$ was lower than the $\mathrm{C}$-organic content at a depth of $15-45 \mathrm{~cm}$ and $45-100 \mathrm{~cm}$.

The peat from West Kalimantan contains C-organic that was also significantly different between the depths of peat and this occurs in all types of land use except for oil palm plantation. The content of C-organic at a depth of $0-15 \mathrm{~cm}$ lower than the organic $\mathrm{C}$ content at a depth of 15$45 \mathrm{~cm}$ and $45-100 \mathrm{~cm}$.

More intensive management on top layer of peat and followed by the application of fertilizers and ameliorant materials are expected to result in decomposition of the peat layer more quickly than the lower layers of peat, so that the organic $\mathrm{C}$ content in the upper layers is lower.

The number of bacteria was significantly different among the types of land use, and these differences were found both in Central Kalimantan and West Kalimantan. In Central Kalimantan, it seems that the duration of land management affects the number of bacteria. Land managed for 10 years contain the number of bacteria that ranged from 5.42 to $6.20(\mathrm{Cfu} / \mathrm{g}$ $\mathrm{x} 105)$, higher than the number of bacteria on land that is managed for 5 years, which ranged from 2.36 to 3.46 (Cfu/g x 105). In West Kalimantan, the highest number amounts to 4.50 bacteria (Cfu I $g$ x 105), which occurs on Aloe vera fields. 


\section{Carbon Dioxide Emissions and environmental factors}

The measurement of $\mathrm{CO}_{2}$ emission from the four types of peatland use in Central Kalimantan showed that the highest $\mathrm{CO}_{2}$ emission was from sweet corn field (for 10 years) at $0.79 \mathrm{~g}$ $\mathrm{CO}_{2} / \mathrm{m}^{2} /$ hour, followed by chinesse cabbage field (for 5 years) at $0.73 \mathrm{~g} \mathrm{CO}_{2} / \mathrm{m}^{2} /$ hour. Chinesse cabbage field (for 10 years) at $0.67 \mathrm{~g} \mathrm{CO}_{2} / \mathrm{m}^{2} /$ hour and sweet corn field (5 years) at 0.41 $\mathrm{gCO}_{2} / \mathrm{m}^{2} /$ hour, each on the condition of the groundwater table depth of $46.11 \mathrm{~cm}, 39.06 \mathrm{~cm}$, $42.94 \mathrm{~cm}$ and $24.10 \mathrm{~cm}$, respectively.

In general, the four types of land use in Central Kalimantan release of $\mathrm{CO}_{2}$ emissions in relatively equal amounts. This might be due to the fact that the four types of land were located in one area, so that environmental factors such as the depth of groundwater table, temperature and degree of decomposition are relatively similar. Also, both chinesse cabbage and sweet corn plants share the same root system, that is, the short fibrous roots. With almost similar environmental conditions and similar root systems, the released amounts of $\mathrm{CO}_{2}$ are differing only slightly.

The amounts of $\mathrm{CO}_{2}$ emitted by the four types of land use in Central Kalimantan were no too much differ from those of Hatano et al. (2004), which suggests that Kalampangan peatlands with groundwater depth ranges from 61$77 \mathrm{~cm}$, emit the $\mathrm{CO} 2$ at 0.23 to $1.02 \mathrm{~g}$ $\mathrm{CO}_{2} / \mathrm{m}^{2} /$ hour. However, it is much higher when compared to the results of the study by Jauhiainen et al. (2004) indicating that abandoned agricultural land releases of $0.22 \mathrm{~g} \mathrm{CO}_{2} / \mathrm{m}^{2} /$ hour emissions.

The high $\mathrm{CO}_{2}$ emissions by chinesse cabbage field and sweet corn field might be due to the relatively fertile peatlands with applied fertilizer, ameliorant and crop residues, when compared to open and abandoned land. Sri Nuryani et al. (2009) indicated that some of abandoned peatlands in Berengbengkel underwent changes from hydrophilic to hydrophobic in nature. Hydrophilic peat emits $\mathrm{CO} 2$ in higher amount than that of the hydrophobic peat.

Results obtained from $\mathrm{CO}_{2}$ emission measurement in the 4 types of land use in West Kalimantan showed that the highest emissions are from the rubber plantation at $1.22 \mathrm{~g} \mathrm{CO}_{2} / \mathrm{m}^{2} /$ hour, followed by oil palm plantation at $0.96 \mathrm{~g} \mathrm{CO}_{2} / \mathrm{m}^{2} /$ hour, Aloe vera field at 0.68 of $\mathrm{CO}_{2} / \mathrm{m}^{2} /$ hour and corn field at $0.35 \mathrm{~g} \mathrm{CO} / \mathrm{Cm}^{2} /$ hour, with the condition of the groundwater table depths of 77.92 $\mathrm{cm}, 64.11 \mathrm{~cm}, 53.74 \mathrm{~cm}$ and $21.84 \mathrm{~cm}$, respectively.

Differences in plant species in each type of land use or different growing environments result in differences in physiology, especially in the root system. Rubber, oil palm, Aloe vera and corn plants have different morphology and root system. In terms of morphology, rubber and oil palm trees have leaves in large numbers and wide canopy of leaves, thus affecting the microenvironmental conditions, especially temperature around the plants and soil temperature. In terms of rooting, rubber and oil palm trees have thicker and longer root, so that the radius of root distribution was also increasingly farther compared to that of Aloe vera and corn plants.

In West Kalimantan, the $\mathrm{CO}_{2}$ emissions from rubber plantation amount to $1.22 \mathrm{~g}$ $\mathrm{CO}_{2} / \mathrm{m}^{2} /$ hour on the water table depth of $77.9 \mathrm{~cm}$, higher than the $\mathrm{CO}_{2}$ emissions from oil palm plantation at $0.96 \mathrm{~g} \mathrm{CO}_{2} / \mathrm{m}^{2} /$ hour on water table depth of $64.1 \mathrm{~cm}$. These results contradict the predictions by Agus and Subiksa (2008) who noted that the $\mathrm{CO}_{2}$ emissions from rubber plantation was only about $0.42 \mathrm{~g} \mathrm{CO}_{2} / \mathrm{m}^{2} /$ hour assuming that the water table depth is about $20 \mathrm{~cm}$ and is lower than $\mathrm{CO}_{2}$ emissions from oil palm plantation. Oil palm plantation emits $\mathrm{CO}_{2}$ at 0.96 $\mathrm{g} \mathrm{CO}_{2} / \mathrm{m}^{2} /$ hour, higher than the results of Melling (2005) on oil palm plantation in Sarawak emitting $0.69 \mathrm{~g} \mathrm{CO}_{2} / \mathrm{m}^{2} /$ hour.

Depth of groundwater level shows a consistent effect on $\mathrm{CO}_{2}$ emissions. The lower the depth of the groundwater table, the higher the amount of $\mathrm{CO}_{2}$ emission. $\mathrm{CO}_{2}$ emission rate shows a linear relationship with the groundwater table depth (Jauhiainen et al., 2005; Hooijer et al., 2006; Agus et al., 2010; Jauhiainen and Hooijer., 2012). On tropical peat, water table depth plays more significant role compared to the temperature in controlling $\mathrm{CO}_{2}$ emissions. It is also supported by Hirano et al. (2009), noting that the hydrology is one of the abiotic factors that are important in controlling the balance of carbon in tropical peat due to smaller variations in soil temperature and the air temperature in the tropics compared to that of subtropical peat.

The groundwater table depth in Central Kalimantan ranges from 24.1 to $46.1 \mathrm{~cm}$, and the water table depth in West Kalimantan ranges from 21.8 to $77.9 \mathrm{~cm}$. Groundwater depth ranges, both in Central Kalimantan and West Kalimantan, are still within the normal range. According Hooijer et al. (2006), the optimal groundwater table depth 
for peatlands cultivated with annual plants is about $33 \mathrm{~cm}$ and the groundwater table depth for plantations is about $95 \mathrm{~cm}$. And according to Morrison et al. (2012), the optimal groundwater table depth for plantation crops ranges from 60 to $80 \mathrm{~cm}$.

$\mathrm{CO}_{2}$ emissions from rubber plantation and palm oil field are higher than those of corn and Aloe vera fields. The high $\mathrm{CO}_{2}$ emissions from the rubber plantation and oil palm fields might be attributed, largely, to the roots and rhizosphere respirations. Such expectation is associated with the correlation between air and soil temperature and $\mathrm{CO}_{2}$ emissions. Air and soil temperature decreased, while $\mathrm{CO}_{2}$ emissions increased. This applies also to the correlation between the content of organic matter and $\mathrm{CO}_{2}$ emissions, where the higher the organic matter content, the higher the $\mathrm{CO}_{2}$ emitted. It is most likely that $\mathrm{CO}_{2}$ emissions from rubber and oil palm plantations were not entirely derived from oxidation of soil organic matter and litter decomposition. According to Hirano et al. (2009), $\mathrm{CO}_{2}$ emission from root respiration is inseparable from the emissions caused by decomposition. Root respiration magnitude range varies widely from 10 to $90 \%$ of total soil respiration. However, on average, they amount to almost $50 \%$ of total soil respiration (Hanson et al., 2000 in Luo and Zhou, 2006). According Moyano et al. (2010), emission of $\mathrm{CO}_{2}$ from root respiration may be greater in number than that of decomposition of soil organic matter.

\section{Carbon sequestration by plants}

$\mathrm{CO}_{2}$ emissions and carbon sequestration in peatland take place simultaneously, but the amount of each depends on the ecological condition and human intervention. The effect of plant species on the ability of plants to sequestrate carbon can be seen from the very large difference between sweet corn and chinesse cabbage plants, where the former may generate $\mathrm{C}$ at 9.02 to 14.30 $\mathrm{t}$ of $\mathrm{C} / \mathrm{ha} /$ year, comprising of stems $(46.00 \%)$, leaves $(24.65 \%)$, corn skins $(16.85 \%)$ and roots (12.5\%). Chinesse cabbage plant can only generate $\mathrm{C}$ at 1.48 to $1.80 \mathrm{t}$ of $\mathrm{C} / \mathrm{ha} / \mathrm{year}$, consisting of leaves $(82.98 \%)$, trunks $(9.75 \%)$ and roots $(7.27 \%)$.

During the plant growth carbon sequestration will occur, the amount of which determined by the amount of biomass. Both in chinesse cabbage and sweet corns, their roots contribute insignificantly to the amount of biomass. Page et al. (2004) noted that, while the roots contribute insignificantly to the total biomass, they play critical role in accumulating peats because of very slow decomposition of roots. Plant leaves have a high enough contribution to biomass production, but due to the fast decomposition of leaf tissue, it available only in a small amount in peat accumulation (Verwer et al., 2008).

Chinesse cabbage plants have a huge gap between the amount of $\mathrm{CO}_{2}$ emissions, i.e, an average of $16.69 \mathrm{t}$ of $\mathrm{C} / \mathrm{ha} / \mathrm{year}$ and the ability of the plants to tie $\mathrm{C}$, which is an average of $1.64 \mathrm{t}$ of $\mathrm{C} / \mathrm{ha} /$ year. The average emission from corn fields is $14.29 \mathrm{t}$ of $\mathrm{C} / \mathrm{ha} / \mathrm{year}$, and the ability to tie up carbon is $11.66 \mathrm{t}$ of $\mathrm{C} / \mathrm{ha} / \mathrm{year}$. The results of this study are far greater than those of Agus and Subiksa (2008) which reported that the average amount of carbon stored in the biomass of corn plants ranged from 1 to $3 \mathrm{t}$ of $\mathrm{C} / \mathrm{ha} / \mathrm{year}$. The ability of corn plants to generate $\mathrm{C}$ was lower than the $\mathrm{C}$ loss from peatlands. However, corn plants have a great potential to generate $\mathrm{C}$ and to maintain a balance between the $\mathrm{C}$ loss and the generated $\mathrm{C}$ as compared to chinesse cabbage.

Both oil palm and rubber plantation indicate a large gap between $\mathrm{CO}_{2}$ emissions from each land and the ability of plants to sequestrate C. $\mathrm{CO}_{2}$ emission from oil palm field is at $23.05 \mathrm{t}$ $\mathrm{C} /$ ha/year, while the ability of oil palm sequestrate carbon is only at 2.44 ton C/ha/year (Rogi, 2002; Agus and Subiksa, 2008). In rubber plantation, $\mathrm{CO}_{2}$ emissions amount to $29.15 \mathrm{t} \mathrm{C} / \mathrm{ha} /$ year, while its ability to sequestrate $\mathrm{C}$ is only at $2.56 \mathrm{t}$ $\mathrm{C} /$ ha/year (Agus and Subiksa, 2008). Both rubber and oil palm plantation generate lower $\mathrm{C}$ than Acacia plantations which is able to generate $\mathrm{C}$ at $6.38 \mathrm{t} \mathrm{C} / \mathrm{ha} /$ year, and is higher than the $\mathrm{C}$ generated by peat swamp forest, which is at $5.52 \mathrm{t}$ C/ha/year (Djajakirana et al., 2012).

\section{CONCLUSION}

\section{Carbon dioxide $(\mathrm{CO} 2)$ emissions}

$\mathrm{CO} 2$ emissions obtained in this study are not merely generated by peat decomposition process, but also contributed by plant root respiration. Land use type, both the cultivated commodities and the cultivating duration, found to emit $\mathrm{CO} 2$ with varied values, despite the fact that in 2006, in Central Kalimantan, the four types of land use indicated no significant differences in terms of $\mathrm{CO} 2$ emission.

Based on average $\mathrm{CO} 2$ emissions measured in 2006 and 2007 in Central Kalimantan, the highest emissions are those from 
sweet corn field (arable land for 10 years), followed by chinesse cabbage field (for 5 years), chinesse cabbage field (for 10 years) and sweet corn field (for 5 years) by $0,79,0,73,0,67$ and $0,43 \mathrm{~g} \mathrm{CO} 2 / \mathrm{m} 2 /$ hour, respectively. In the four types of land use, $\mathrm{CO} 2$ emission levels decline over time, from $0,56-0,82 \mathrm{~g} \mathrm{CO} 2 / \mathrm{m} 2 /$ hour (2006) to $0,29-0,77 \mathrm{~g} \mathrm{CO} 2 / \mathrm{m} 2 /$ hour (2007).

In West Kalimantan, of the average $\mathrm{CO} 2$ emissions measured in 2006 and 2007, the highest being those released by rubber plantation at $1,22 \mathrm{~g}$ $\mathrm{CO} 2 / \mathrm{m} 2 /$ hour, followed by oil palm plantation at $0,97 \mathrm{~g} \mathrm{CO} 2 / \mathrm{m} 2 /$ hour, aloe vera field at 0.68 of $\mathrm{CO} 2 / \mathrm{m} 2 /$ hour, and corn field at $0,35 \mathrm{~g}$ $\mathrm{CO} 2 / \mathrm{m} 2 /$ hour. Meanwhile, $\mathrm{CO} 2$ emissions from the three types of land use (corn, aloe vera, and palm threes) increase, i.e, corn field from $0,30 \mathrm{~g}$ $\mathrm{CO} 2 / \mathrm{m} 2 /$ hour (2006) to $0,39 \mathrm{~g} \mathrm{CO} 2 / \mathrm{m} 2 /$ hour (2007), aloe vera field from $0,64 \mathrm{~g} \mathrm{CO} 2 / \mathrm{m} 2 /$ hour (2006) to $0,72 \mathrm{~g} \mathrm{CO} 2 / \mathrm{m} 2 /$ hour (2007), oil palm plantation from $0,78 \mathrm{~g} \mathrm{CO} 2 / \mathrm{m} 2 /$ hour (2006) to $1,15 \mathrm{~g} \mathrm{CO} 2 / \mathrm{m} 2 /$ hour (2007). The emission from rubber plantation declined insignificantly from $1,26 \mathrm{~g} \mathrm{CO} 2 / \mathrm{m} 2 /$ hour (2006) to $1,18 \mathrm{~g}$ $\mathrm{CO} 2 / \mathrm{m} 2 /$ hour (2007).

2. Peat characteristics that affect $\mathrm{CO} 2$ emissions

In Central Kalimantan, the physical, chemical and biological properties of peat that affect and significantly correlated with the amount of $\mathrm{CO} 2$ emitted from the types of land use are the cation-exchange capacity (CEC), groundwater level, $\mathrm{pH}$ of H2O, K-total. As for those in West Kalimantan, they are cation-exchange capacity (CEC), groundwater level, $\mathrm{pH}$ of $\mathrm{H} 2 \mathrm{O}$, soil temperature, and organic $\mathrm{C}$. The increased $\mathrm{CO} 2$ emission might be caused by the decreasing groundwater level, soil temperature, and increased $\mathrm{pH}$ of $\mathrm{H} 2 \mathrm{O}, \mathrm{CEC}$, K-total, and organic $\mathrm{C}$ content.

Variations in $\mathrm{pH}(\mathrm{H} 2 \mathrm{O})$ for two-years period in types of land use and depth of sampling were 3,07 - 3,43 (Central Kalimantan) and 3,22 3,87 (West Kalimantan). The groundwater levels in Central Kalimantan and West Kalimantan are $18,10-55,25 \mathrm{~cm}$ and $19,34-87,25 \mathrm{~cm}$, respectively. CEC values are higher on topsoil layer $(0-15 \mathrm{~cm})$ and decreasing in sample depth of $45-100 \mathrm{~cm}$, which indicate the growth of microorganism that enable them to rapidly decompose organic matter in water unsaturated layer of peat. Variations in CEC values in all types of land use and depth of peat sample in Central Kalimantan and West Kalimantan are $159,33-253,92 \mathrm{cmol}(+) / \mathrm{kg}$ and $145,65-271,43$ $\mathrm{cmol}(+) / \mathrm{kg}$, respectively. The varied average values of the three macro elements that affect only the $\mathrm{CO} 2$ emission in Central Kalimantan are Ktotal 69,88 - 106,34 mg/100g, Ca-total 20,88 $28,49 \mathrm{~g} / \mathrm{kg}$, and Mg-total. As for the soil temperature and organic $\mathrm{C}$ that only affect the $\mathrm{CO} 2$ emission in West Kalimantan, the variation in their values are $27,83-30,56 \mathrm{oC}$ and organic $\mathrm{C}$ of $56,49-57,91 \%$.

3. Plant Carbon sequestration

Plant $\mathrm{C}$ sequestration is greatly determined by the species and duration of cultivation. Average values of sequestrated $\mathrm{C}$ in four types of land use in Central Kalimantan are $1,48 \mathrm{t}$ of $\mathrm{C} / \mathrm{ha} / \mathrm{year}$ for chinesse cabbage (5 years), $1,80 \mathrm{t}$ of $\mathrm{C} / \mathrm{ha} / \mathrm{year}$ for chinesse cabbage $(10$ years), $9,02 \mathrm{t}$ of $\mathrm{C} / \mathrm{ha} /$ year for sweet corn (5 years), and 14,30 t C/ha/year for sweet corn (10 years). Meanwhile, the carbon sequestrated by corn plants studied in West Kalimantan amounts, in average, to $11,66 \mathrm{t} \mathrm{C} /$ ha/year. The secondary data (of previous research) indicates that oil palm plantations generate $2,44 \mathrm{t}$ of $\mathrm{C} / \mathrm{ha} /$ year, rubber plantations generate $2,56 \mathrm{t}$ of $\mathrm{C} / \mathrm{ha} / \mathrm{year}$, while the data for aloe vera field was not available. From $\mathrm{CO} 2$ emission level in each type of land use, in terms of differences between $\mathrm{CO} 2$ emission and plant carbon sequestration in four types of land use in Central Kalimantan, chinesse cabbage (of arable land for 5 years) has the largest deficit rate at $-12,24 \mathrm{t}$ of $\mathrm{C} / \mathrm{ha} / \mathrm{year}$, followed by chinesse cabbage (for 10 years) at $-10,84 \mathrm{t}$ of $\mathrm{C} / \mathrm{ha} /$ year, sweet corn (for 10 years) at $-0,58 \mathrm{t}$ of $\mathrm{C} / \mathrm{ha} / \mathrm{year}$. In the sweet corn field by additional at 1,32 $\mathrm{t}$ of $\mathrm{C} / \mathrm{ha} /$ year and. While no deficit in corn commodity was found in West Kalimantan, which remains at 3,45 $\mathrm{t}$ of $\mathrm{C} / \mathrm{ha} / \mathrm{year}$, the highest deficit was found in rubber commodity at $-26,59 \mathrm{t}$ of $\mathrm{C} / \mathrm{ha} /$ year, followed by palm plantation at $-20,61 \mathrm{t}$ $\mathrm{C} / \mathrm{ha} /$ year.

\section{LITERATURE CITED}

Agus, F., dan I.G.M. Subiksa. 2008. Lahan Gambut: Potensi untuk Pertanian dan Aspek Lingkungan. Balai Penelitian Tanah dan World Agroforestry Centre (ICRAP). Bogor. Indonesia. 36.

Agus, F., Wahyunto., A. Dariah., P. Setyanto., I.G.M. Subiksa., E. Runtunuwu., E. Susanti., and W. Supriatna. 2010. Carbon Budget and Management Strategies for Conserving Carbon in Peatland: Case study in Kubu Raya and Pontianak Districts, West Kalimantan, Indonesia. Proceeding of International 
Workshop on Evaluation and Sustainable Management of Soil Carbon Sequestration in Asian Countries. September 28-29, 2010, Bogor, Indonesia

Andriesse, J.P. 1988. Nature and Management of Tropical Peat Soils. FAO Soils Bulletin 59. FAO, Roma. 165

Collins, M. E., and R. J. Kuehl. 2001. Organic Matter Accumulation and Organic Soil. Dalam: Richardson, J.L., and M.J. Vepraskas. (eds.). Wetlands Soils. Genesis, Hydrology, Landscapes, and Classification. Lewis Publishers. Boca Raton-London-New York-Washington DC. 137-162

Djajakirana, G., A. Puspasari., M. Permatasari., M. Soesanto., and S. Maria. 2012. Pattern of Biological Activities in Various Conditions of Planted Acacia Crassicarpa on Peatlands in Relation to Carbon Emission.Dalam: Peatlands in Balance. Proceeding of the 14th International Peat Congress, Stockholm, Sweden.

Hatano, R., T. Morishita., U. Darung., S.H. Limin., and A. Anwar. 2004. Impact of Agriculture and Wildfire on $\mathrm{CO}_{2}, \mathrm{CH}_{4}$ and $\mathrm{N}_{2} \mathrm{O}$ Emissions from Tropical Peatland in Central Kalimantan, Indonesia., Necessity of Establishment of Inventory on Carbon Cycling in Tropical Peatland Ecosystem for Sustainable Agroproduction and Enviromental Conservation, Report number 13574012, Field Science Centre for Northern Biosphere, Hokkaido University, Sapporo. 11-14.

Hirano, T., H. Segah., T. Harada., S. Limin., T.June., R. Hirata., and M. Osaki. 2007. Carbon dioxide balance of tropical peat swamp forest in Kalimantan, Indonesia, Global Change Biology. 13:1-14.

Hirano, T., J. Jauhiainen., T. Inoue., and $\mathrm{H}$. Takahashi. 2009. Controls on the carbon balance of tropical peatlands. Ecosystem 12: 873-887

Hooijer, A., M. Silvius., H. Wösten., and S.E. Page. 2006. PEAT- $\mathrm{CO}_{2}$, Assessment of $\mathrm{CO}_{2}$ emissions from drained peatlands in SE Asia. Delft Hydraulics report Q3943. 36

Inubushi, K., Y. Furakawa., A. Hadi., E. Purnomo., and H. Tsuruta. 2003. Seasonal change of $\mathrm{CO}_{2}, \mathrm{CH}_{4}$ and $\mathrm{N}_{2} \mathrm{O}$ fluxes in relation to land-use change in tropical peatlands located in coastal area of South Kalimantan, Chemosphere. 52:603-608
IPPC-Intergovernmental Panel on Climate Change. 2001. Climate Change 2001: The Scientific basis. Contribution of Working Group 1 to the Third Assessment Report of the Intergovernmental Panel on Climate Change.Houghton, J.T., Ding, Y., Griggs, D.J., Noguer, M., van der linden, P.J., Xiaosu, D. Cambridge University Press Cambridge.

Jauhiainen, J., J. Heikkinen., P.J. Martikainen., and $\mathrm{H}$. Vasander. 2001. $\mathrm{CO}_{2}$ and $\mathrm{CH}_{4}$ fluxes in pristine peat swamp forest and peatland converted to agriculture in Central Kalimantan, Indonesia. Dalam: Rieley, J.O and S.E. Page. (eds.). International Peat Journal.International Peat Society.Jyväskylä, Finland. 12:43-49

Jauhiainen, J., H. Vasander., A. Jaya., T. Inoue., J. Heikkinen., and P. Martikainen. 2004. Carbon balance in managed tropical peat in Central Kalimantan, Indonesia. Dalam: Päivänen, J. (ed.). Wise Use of Peatlands. Proceeding of the $12^{\text {th }}$ International Peat Congress. Tampere, Finland. Publisher International Peat Society, Vapaudenkatu, Jyväskylä, Finland. 653-658

Jauhiainen, J., H.Takahashi., J.E.P. Heikkinen., P.J.Martikainen., and H. Vasander. 2005. Carbon fluxes from a tropical peat swamp forest floor. Global Change Biology. 11:1788-1797

Jauhiainen, J., S. Limin., H. Silvennoinen., and H. Vasander. 2008. Carbon dioxide and methane fluxes in drained tropical peat before and after hydrological restoration. Ecology, 89(12):3503-3514

Jauhiainen, J., and A. Hooijer. 2012. Greenhouse gas emissions from a plantation on thick tropical peat. Dalam: Peatlands in Balance. Proceeding of the 14th International Peat Congress, Stockholm, Sweden.

Jauhiainen, J., A. Hooijer., and S.E. Page. 2012. Carbon dioxide emissions from an Acacia plantation on Sumatra, Indonesia. Biogeosciences. 9: 617-630. doi: 10.5194/bg9-617-2012

Kawahigashi, M., and H. Sumida. 2006. Humus composition and physicochemical properties oh humic acids in tropical peat soils under sago palm plantation. Soil Science and Plant Nutrition 52(2):153-161

Luo, Y and Zhou, X. 2006. Soil Respiration and the Environment. Academi Press. 317 
Melling, L. 2005. Greenhouse gas fluxes from tropical peatland of Sarawak, Malaysia. Ph.D Thesis.Soil Science Laboratory.Division of Environmental Resources. Graduate School of Agriculture. Hokkaido University. Japan. 200

Morrison, R., and S.E. Page. 2012. Assessing the empirical basis of peat $\mathrm{CO} 2$ emissions estimates from oil palm plantations on tropical peatland. Dalam: Peatlands in Balance. Proceeding of the 14th International Peat Congress, Stockholm, Sweden.

Moyano, F. E., O. K. Atkin., M. Bahn., D. Bruhn., A. J. Burton., A. Heinemeyer., W. I. Kutsch., and G.Wieser. 2010. Respiration from roots and the mycorrhizosphere. Dalam: Kutsch, W.I., M. Bahn., and A. Heinemeyer. (eds.). Soil Carbon Dynamics. An Integrated Methodology. Cambridge University Press. 127-156

Page, S.E., R.A.J.Wüst., D. Weiss.,J.O.Rieley., W. Shotyk., and S.H.Limin. 2004. A record of late Pleistocene and Holocene carbon accumulation and climate change from an equatorial peat bog (Kalimantan, Indonesia: implication for past, present and future carbon dynamics. Journal of Quatenary Science. 19(7):625-635

Pirkko, S., and T. Nyronen.1990. The carbon dioxide emissions and peat production.International Conference on Peat Production and Use. Jiväskylä. Finland. 1:150-157

Reddy, K.R., and R. D. Delaune. 2008. Biogeochemistry of Wetlands. Science and Applications. CRP Press. Taylor \& Prancis Group. 806

Rieley, J. 1992. The ecology of tropical peatswamp forest - A Southeast Asian perspective.Dalam: Aminuddin, B.Y., S.L. Tan., B. Aziz., J. Samy., Z. Salmah., H.S. Petimah., and S.T.Choo. (eds.). Tropical Peat. Proceedings of the International Symposium on Tropical Peatland. MARDI, Malaysia. 224-254

Rieley, J.O., R.A.J.Wüst., J. Jauhiainen., S.E. Page., H. Wösten., A.Hoijer.,F. Siegert., S. Limin., H. Vasander., and M. Stahlhut. 2008. Tropical peatlands: carbon store, carbon gas emissions and contribution to climate change processes. Dalam: Strack, M. (ed.), Peatlands and Climate Change. Publisher International Peat Society, Vapaudenkatu, Jyväskilä, Finland. 149-181
Rogi, J.E.X. 2002. Penyusunan model simulasi dinamika nitrogen pertanaman kelapa sawit (Elaeis guineensis, Jacq.) di unit usaha Bekri Propinsi Lampung. Disertasi. Institut Pertanian Bogor.

Sjarkowi, F. 2007. Is Poverty eradication possible in the peatland areas of Central Kalimantan, Indonesia. Dalam: Rieley, J.O., S.H.Limin and A.Jaya. (eds.) Restoration and Wise Use of Tropical Peatland: Problem of Biodiversity, Fire, Poverty and Water Management. Proceeding of the International Symposium and Workshop on Tropical Peatland. Palangka Raya, 20-24 September 2005, EU RESTORPEAT Partnership, University of Palangka Raya, Indonesia and Wageningen University and Research Institute, The Netherlands. 19-32

Sri Nuryani, H, U., A.Maas., B.H. Purwanto and B. Radjagukguk. 2009. Effects of surfactant and ameliorant on effectiveness of $\mathrm{P}$ fertilizer on hidrofobik peat from Central Kalimantan. Jurnal Ilmu Tanah dan Lingkungan, 9(2):103-103

Strack, M., J. M, Waddington., M. Turetsky., N.T. Roulet and K. Byrne. 2008. Northern peatlands, greenhouse gas exchange and climate change. Dalam: Strack, M. (ed.).Peatlands and Climate Change.Publisher International Peat Society, Vapaudenkatu, Jyväskilä, Finland. 44-69

Verwer, C., P. van der Meer and G-J. Nabuurs. 2008. Review of carbon flux estimates and other greenhouse gas emissions from oil palm cultivation on tropical peatlandsIdentifying the gaps in knowledge. Alterrarapport 1731.Alterra, Wageningen. 44. 